\title{
Urgences
}

\section{Feutre noir cheveux roses}

Nouvelle Élément

Numéro 20, mai 1988

Appellation contrôlée

URI : https://id.erudit.org/iderudit/025467ar

DOI : https://doi.org/10.7202/025467ar

Aller au sommaire du numéro

Éditeur(s)

Urgences

ISSN

0226-9554 (imprimé)

1927-3924 (numérique)

Découvrir la revue

Citer cette note

Élément, N. (1988). Feutre noir cheveux roses. Urgences, (20), 18-19.

https://doi.org/10.7202/025467ar

Ce document est protégé par la loi sur le droit d'auteur. L'utilisation des services d'Érudit (y compris la reproduction) est assujettie à sa politique d'utilisation que vous pouvez consulter en ligne.

https://apropos.erudit.org/fr/usagers/politique-dutilisation/
Cet article est diffusé et préservé par Érudit.

Érudit est un consortium interuniversitaire sans but lucratif composé de l’Université de Montréal, l'Université Laval et l'Université du Québec à Montréal. Il a pour mission la promotion et la valorisation de la recherche. https://www.erudit.org/fr/ 


\section{NOUVELLE ÉLÉMENT \\ Feutre noir cheveux roses}

Elle n'avait jamais pensé à ses cheveux. Il y avait les lunettes, l'imperméable, le sac à double-fond, le revolver sous l'aisselle, les semelles de crêpe. Son patron lui avait suggéré un faux nez, de fausses dents, lui avait pris rendez-vous chez une maquilleuse de thêatre, lui avait rappelé: faites-vous teindre les cheveux.

Elle avait oublié.

Rien de plus.

Pas beaucoup moins.

Elle se regarda dans le miroir, ne se reconnut évidemment pas, tâta son nez, ses dents, ses joues même, les trouva fausses, sentant le plastique et la farine puis elle regarda ses cheveux roses à nouveau. Elle avait oublié.

Le patron avait dit: noir, teignez-les en noir, personne ne vous reconnaîtra.

Elle fouilla dans les armoires du bureau, ne trouva rien, elle fouilla chez elle et ne trouva rien de mieux, alors elle courut chez Eaton, acheta le chapeau le plus large qu'elle put trouver et s'en couvrit la tête jusqu'aux yeux.

Elle avait oublié.

On ne pouvait se souvenir de tout.

Toujours.

Être totalement sans faille et sans erreur. Elle enfonça le chapeau, le coinça contre les lunettes fumées, remonta le col de son imperméable, serra sa ceinture, frotta ses bottes contre ses mollets. Elle était prête.

Personne ne pouvait voir les mèches de cheveux roses - le patron disait «fuchsia» en la taquinant - dépasser du feutre. Elle aurait pu jouer le rôle de Bogart dans Casablanca, imiter Colombo ou Cagney \& Lacey dans leurs déguisements les plus ahurissants. Elle était prête.

Elle ajouta un grain de beauté au crayon gras. Elle le plaça au dessus de la lèvre supérieure, se trouva un air de vamp, se dit que sa mère même sa mère ne pourrait... 
Elle prit son sac, vérifia ses papiers, puis elle héla un taxi.

Le patron n'y verrait que du feu.

Elle avait oublié.

Il y avait eu tant et tant à faire.

Un détail - le feutre cachait tout - ne pouvait faire rater le coup.

Elle avait oublié.

Elle était prête.

Elle entra dans le bureau. Le patron lui dit de suivre les autres. Les auditions allaient commencer. 